\title{
Gambaran anemia defisiensi besi pada pasien penyakit ginjal kronik stadium V yang menjalani hemodialisis di Instalasi tindakan hemodialisis RSUP Prof. Dr. R. D. Kandou Manado
}

\author{
${ }^{1}$ Felix E. Suyatno \\ ${ }^{2}$ Linda W. A. Rotty \\ ${ }^{2}$ Emma S. Moeis
}

\author{
${ }^{1}$ Kandidat Skripsi Fakultas Kedokteran Universitas Sam Ratulangi Manado \\ ${ }^{2}$ Bagian Ilmu Penyakit Dalam Fakultas Kedokteran Universitas Sam Ratulangi Manado \\ Email: felix.erlangga@gmail.com
}

\begin{abstract}
Chronic kidney disease (CKD) is a pathophysiological process with varied etiology, results in progressive decrease of renal function, and generally ends up with renal failure. Data from Indonesian Association of Nephrology (PERNEFRI) in 2012 showed that $83 \%$ of all patients who underwent hemodialysis were with end-stage renal disease (ESRD) which is the terminal stage of CKD. In patients with CKD, there can be a wide variety of complications; one of them is anemia. This study aimed to obtain the overview of iron deficiency anemia of stage V CKD patients who were treated with hemodialysis in hemodialysis center of Prof. Dr. R. D. Kandou Central General Hospital Manado. This was a descriptive study with a cross sectional approach conducted from October to December 2015 in Prof. Dr. R. D. Kandou Hospital. Variables were age, sex, laboratory result, duration of hemodialysis, and the diagnosis of iron deficiency anemia. The results showed that there were 39 samples; females were 21 patients (53.8\%). The largest age group was $>60$ years with 16 patients (41\%). The degree of anemia mostly found was the moderate degree with 26 patients (66.7\%). Five patients (12.8\%) were diagnosed with iron deficiency anemia. Conclusion: In this study, the most common degree of anemia was moderate, followed by severe and slight anemia consecutively. Iron deficiency anemia cases were $12.8 \%$.
\end{abstract}

Keywords: chronic kidney disease, iron deficiency anemia, serum iron, transferrin saturation

\begin{abstract}
Abstrak: Penyakit ginjal kronik (PGK) adalah suatu proses patofisiologik dengan etiologi beragam, mengakibatkan penurunan fungsi ginjal yang progresif, dan umumnya berakhir dengan gagal ginjal. Data dari Perkumpulan Nefrologi Indonesia (PERNEFRI) tahun 2012 menyatakan bahwa 83\% dari seluruh pasien yang menjalani hemodialisis ialah pasien end stage renal disease (ESRD) yang merupakan stadium terminal PGK. Pada pasien PGK, dapat terjadi berbagai macam komplikasi, salah satunya ialah anemia Penelitian ini bertujuan untuk mengetahui gambaran anemia defisiensi besi pada pasien PGK stadium V yang menjalani hemodialisis di Instalasi Tindakan Hemodialisis RSUP Prof. Dr. R.D. Kandou Manado. Penelitian ini menggunakan metode deskriptif dengan pendekatan potong lintang berdasarkan data primer pada Bulan Oktober - Desember 2015. Variabel penelitian yang digunakan yaitu umur, jenis kelamin, hasil laboratorium, lama menjalani hemodialisis, dan diagnosis anemia defisiensi besi. Hasil penelitian memperlihatkan 39 sampel dengan distribusi sampel terbanyak ialah perempuan sebanyak 21 orang (53,8\%), golongan umur terbanyak $>60$ tahun sebanyak 16 orang (41\%), derajat anemia terbanyak ditemukan ialah anemia derajat sedang sebanyak 26 orang $(66,7 \%)$, dan terdapat 5 orang $(12,8 \%)$ yang terdiagnosis anemia defisiensi besi. Simpulan: Pada penelitian ini ditemukan anemia derajat sedang yang terseing, diikuti anemia derajat berat dan ringan. Terdapat 12,8\% pasien dengan anemia defisiensi besi.
\end{abstract}

Kata kunci: penyakit ginjal kronik, anemia defisiensi besi, serum iron, saturasi transferin 
Penyakit Ginjal Kronik (PGK) adalah suatu proses patofisiologis dengan etiologi beragam, mengakibatkan penurunan fungsi ginjal yang progresif, dan pada umumnya berakhir dengan gagal ginjal. ${ }^{1}$ Penyakit ginjal kronik didefinisikan sebagai adanya kerusakan ginjal, dimanifestasikan dengan ekskresi albumin yang abnormal atau penurunan fungsi ginjal, terdapat penurunan laju filtrasi glomerulus (LFG) dan berlangsung lebih dari tiga bulan. ${ }^{1-3}$

Berdasarkan National Institute Diabetes, Digestive and Kidney Diseases (NIDDK), insidens terjadinya PGK tahun 2000 - 2008 pada usia 24 - 64 tahun adalah kurang dari $0,5 \%$, sedangkan insidens dari PGK pada usia diatas 65 tahun mengalami peningkatan antara tahun 2000 dan 2008, dari $1,8 \%$ menjadi $4,3 \% .{ }^{4}$ Insidens penyakit ginjal di negara-negara berkembang diperkirakan sekitar 40-60 kasus perjuta penduduk per tahun. ${ }^{1}$ Penelitian di India menggambarkan bahwa prevalensi PGK (menggunakan CKD-EPI) mencapai 17,2\% pada tahun 2007..$^{5}$ Penyakit ini perlu mendapat perhatian tersendiri mengingat peran ginjal yang sangat vital bagi kelangsungan homeostasis tubuh.

Untuk mengatasi masalah di atas dapat dilakukan berbagai terapi, salah satu diantaranya adalah dengan hemodialisis. Saat ini, hemodialisis merupakan terapi pengganti ginjal yang paling banyak digunakan di Indonesia dan telah terbukti berhasil memperpanjang kehidupan pasien dengan PGK stadium akhir. Pada terapi tersebut fungsi ginjaldalam membersihkan dan mengatur kadar plasma darah digantikan oleh mesin. Proses tersebut cukup efektif untuk menjaga homeostasis tubuh pasien, tetapi harus dilakukan secara rutin dan berkala oleh pasien (berkisar antara 1 - 3 kali seminggu). ${ }^{6}$

Data dari Perkumpulan Nefrologi Indonesia (PERNEFRI) pada tahun 2012, 83\% dari seluruh pasien yang menjalani hemodialisis adalah pasien End State Renal Disease (ESRD) yang merupakan stadium terminal dari PGK, turun 4\% dari data satu tahun sebelumnya yaitu $87 \% .^{7,8}$ Pada pasien PGK, dapat terjadi berbagai macam komplikasi, salah satunya adalah anemia. ${ }^{1,5,7,9}$

Anemia terjadi pada $80-90 \%$ pasien PGK yang mengalami hemodialisis. Anemia pada PGK terutama disebabkan oleh defisiensi hormon eritropoietin. Defisiensi besi merupakan penyebab anemia kedua terbanyak pada pasien PGK yang menjalani hemodialisis. Anemia defisiensi besi pada pasien PGK terutama disebabkan oleh asupan nutrisi yang kurang, gangguan absorbsi, perdarahan kronik, inflamasi atau infeksi, serta peningkatan kebutuhan besi selama koreksi anemia dengan terapi Eritropoietin Stimulating Agent (ESA). ${ }^{5,10}$

Penelitian ini bertujuan untuk mengetahui gambaran anemia defisiensi besi pada pasien PGK stadium $\mathrm{V}$ yang menjalani hemodialisis di Instalasi Tindakan Hemodialisis RSUP Prof. Dr. R.D. Kandou Manado.

\section{METODE PENELITIAN}

Penelitian yang dilakukan bersifat deskriptif dengan pendekatan potong lintang berdasarkan data primer dari penelitian selama dua bulan serta data sekunder dari rekam medik di Instalasi Tindakan Hemodialisis RSUP Prof. Dr. R. D. Kandou Manado. Semua pasien PGK stadium $\mathrm{V}$ yang menjalani hemodialisis di Bagian Penyakit Dalam Prof. Dr. R.D. Kandou Manado Periode Oktober Desember tahun 2015. Instrumen yang digunakan dalam penelitian ini ialah hasil laboratorium dan rekam medik pasien rawat jalan PGK di Instalasi Tindakan Hemodialisis RSUP Prof. Dr. R. D. Kandou Manado. Variabel Penelitian yang diteliti yaitu: umur, jenis kelamin, frekwensi menjalani hemodialisis, lama menjalani hemodialisis, dan hasil laboratorium (hemoglobin, MCV, MCH, MCHC, serum iron, saturasi transferin, TIBC, dan diagnosis anemia defisiensi besi

Pengumpulan data dilakukan dengan melihat catatan rekam medik penderita dengan diagnosis PGK stadium $\mathrm{V}$ dan menjalani hemodialisis di Bagian Penyakit Dalam RSUP Prof. Dr. R. D. Kandou 
Manado periode Oktober - Desember tahun 2015, kemudian dilakukan anamnesis kepada pasien maupun keluarga. Data yang sudah ada dilengkapi dengan data dari pemeriksaan laboratorium pasien. Penyajian data disajikan dalam bentuk tabel distribusi frekuensi dan diagram.

\section{HASIL PENELITIAN}

Berdasarkan penelitian yang dilakukan di Instalasi Hemodialisis Dahlia RSUP Prof. R. D. Kandou Manado periode Oktober 2015-Desember 2015 didapatkan 39 sampel, yang terdiri dari 18 orang lakilaki $(46,2 \%)$ dan 21 orang $(53,8 \%)$ perempuan.

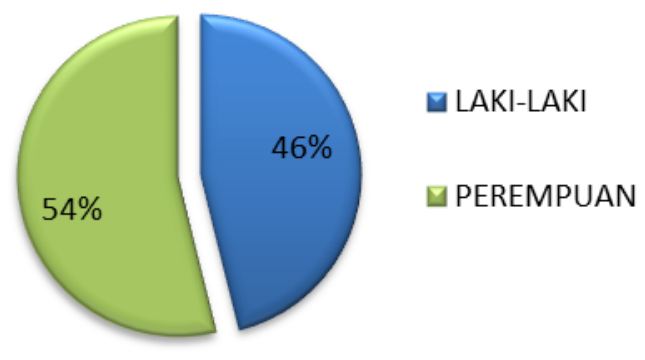

Gambar 1. Distribusi Sampel Berdasarkan Jenis Kelamin

Rerata umur sampel ialah 54,33 tahun, dengan umur minimum 24 tahun dan umur maksimum 75 tahun. Berdasarkan Tabel 1 dapat dilihat bahwa terdapat 16 sampel (41\%) berumur >60 tahun, 13 sampel (33,3\%) berada pada kelompok umur 46-60 tahun, 20,5\% berumur 30-45 tahun, dan sisanya berada dalam kelompok umur $<30$ tahun (Tabel 1).

Tabel 1. Distribusi Sampel Berdasarkan Kelompok Umur

\begin{tabular}{ccc}
\hline $\begin{array}{c}\text { Kelompok Umur } \\
\text { (tahun) }\end{array}$ & \multicolumn{2}{c}{ Jumlah Sampel } \\
n & $(\%)$ \\
\hline$<30$ & 2 & 5,2 \\
$30-45$ & 8 & 20,5 \\
$46-60$ & 13 & 33,3 \\
$>60$ & 16 & 41,0 \\
Total & 39 & 100 \\
\hline
\end{tabular}

Dari penelitian ini didapatkan 38 sampel (97,4\%) melakukan hemodialisis sebanyak 2 kali dalam seminggu dan hanya 1 sampel yang tercatat melakukan hemodialisis sebanyak 3 kali dalam seminggu. Rerata waktu yang dibutuhkan untuk tindakan hemodialisis ialah 4 jam 9 menit, dimana 29 (74,4\%) sampel membutuhkan waktu 4 jam, 8 (20,5\%) sampel membutuhkan waktu 4,5 jam, dan 2 (5,1\%) sampel melakukan hemodialisis selama 5 jam untuk sekali hemodialisis (Gambar 2).

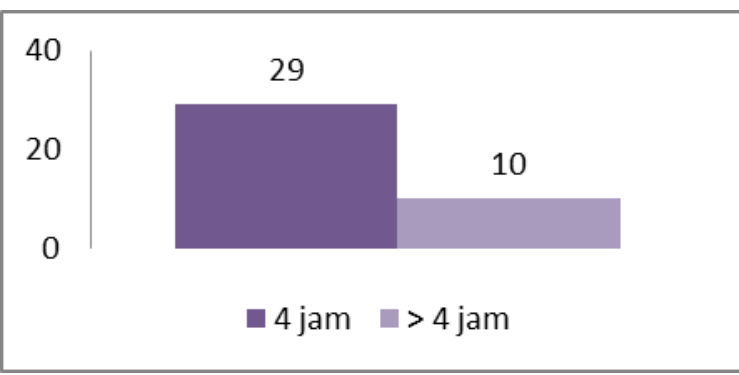

Gambar 2. Distribusi Sampel Berdasarkan Waktu Tindakan

Nilai Hb rata-rata pada sampel adalah 8,7 g/dl, dengan nilai minimum 6,4 g/dl dan nilai maksimum 11,0 g/dl. Pada penelitian yang dilakukan, didapati 11 (28,2\%) sampel mempunyai kadar $\mathrm{Hb}<8,0$ g/dl, 26 (66,7\%) sampel mempunyai kadar Hb 8,0-10,9 g/dl, dan 2 (5,1\%) sampel mempunyai kadar Hb 11 g/dl (Tabel 2).

Tabel 2. Distribusi Jenis Kelamin dan Derajat Anemia Berdasarkan Hb Pada Sampel

\begin{tabular}{ccccc}
\hline \multirow{2}{*}{$\begin{array}{c}\text { Derajat } \\
\text { anemia }\end{array}$} & $\begin{array}{c}c \\
\text { Laki- } \\
\text { laki }\end{array}$ & Penempuan & N & (\%) \\
\hline Ringan & 0 & 2 & 2 & 5,1 \\
Sedang & 12 & 14 & 26 & 66,7 \\
Berat & 6 & 5 & 11 & 28,2 \\
Total & 18 & 21 & 31 & 100 \\
\hline
\end{tabular}

Terdapat 5 sampel yang mempunyai $\mathrm{MCV} \leq 80 \mathrm{fl}, 6$ sampel mempunyai MCV > 95 fl, dan 28 sampel mempunyai MCV sebesar 81 - $95 \mathrm{fl}$. Nilai rerata MCV pada sampel 90,5 fl, dengan nilai minimum $75 \mathrm{fl}$ dan nilai maksimum 102 fl (Gambar 3). Rerata nilai MCH didapatkan sebesar 29,8 
pg, dengan nilai minimum 24 pg, dan nilai maksimum 34 (Tabel 3). Untuk kadar MCHC pada sampel mempunyai rerata sebesar 32,8\%, dengan nilai minimum 31\% dan nilai maksimum 35\% (Tabel 4).

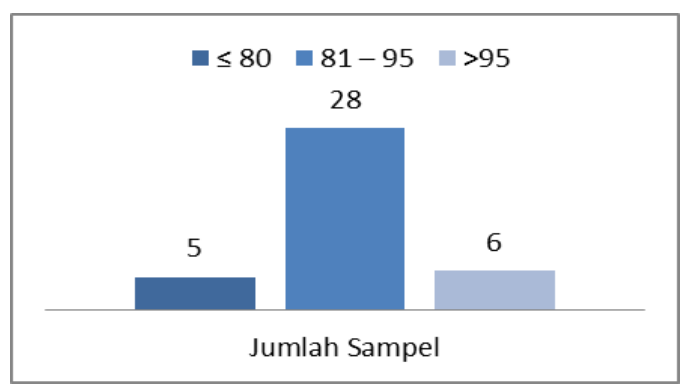

Gambar 3. Distribusi Sampel Berdasarkan MCV

Tabel 3. Distribusi Sampel Berdasarkan MCH

\begin{tabular}{ccc}
\hline \multirow{2}{*}{ MCH (pg) } & \multicolumn{2}{c}{ Jumlah Sampel } \\
n & $(\%)$ \\
\hline$<27$ & 3 & 7,7 \\
$27-34$ & 36 & 92,3 \\
\hline Total & 39 & 100 \\
\hline
\end{tabular}

Tabel 4. Distribusi Sampel Berdasarkan MCHC

\begin{tabular}{ccc}
\hline \multirow{2}{*}{ MCHC (\%) } & $\begin{array}{c}\text { Jumlah Sampel } \\
\mathrm{n}\end{array}$ & $(\%)$ \\
\hline$<32$ & 8 & 20,5 \\
$32-36$ & 31 & 79,5 \\
\hline Total & 39 & 100 \\
\hline
\end{tabular}

Status besi sampel menunjukkan bahwa 26 sampel $(66,7 \%)$ mempunyai nilai serum iron 50-158 $\mu \mathrm{g} / \mathrm{dl}, 3$ sampel $(7,6 \%)$ mempunyai nilai serum iron $>158 \mu \mathrm{g} / \mathrm{dl}$ dengan nilai maksimum $213 \mu \mathrm{g} / \mathrm{dl}$, dan 10 sampel (25,6\%) mempunyai nilai serum iron $<50 \mu \mathrm{g} / \mathrm{dl}$ dengan nilai minimum 29 $\mu \mathrm{g} / \mathrm{dl}$ (Tabel 5).

Tabel 5. Distribusi Sampel Berdasarkan Nilai Serum Iron

\begin{tabular}{ccc}
\hline $\begin{array}{c}\text { Serum Iron } \\
(\mu \mathrm{g} / \mathrm{dl})\end{array}$ & \multicolumn{2}{c}{ Jumlah Sampel } \\
$\mathrm{n}$ & $(\%)$ \\
\hline$<50$ & 10 & 25,6 \\
$50-158$ & 26 & 66,7 \\
$>158$ & 3 & 7,7 \\
Total & 39 & 100 \\
\hline
\end{tabular}

Terdapat 28 sampel dengan saturasi transferin normal, 5 sampel dengan saturasi transferin rendah dan 6 sampel dengan saturasi transferin $>55 \%$ (Tabel 6).

Tabel 6. Distribusi Sampel Berdasarkan Nilai Saturasi Transferin

\begin{tabular}{ccc}
\hline $\begin{array}{c}\text { Saturasi } \\
\text { Transferin (\%) }\end{array}$ & \multicolumn{2}{c}{ Jumlah Sampel } \\
$\mathrm{n}$ & $(\%)$ \\
\hline$<20$ & 5 & 12,8 \\
$20-55$ & 28 & 71,8 \\
$>55$ & 6 & 15,4 \\
\hline Total & 39 & 100 \\
\hline
\end{tabular}

Nilai TIBC pada sampel berdasarkan tabel 14 menunjukkan bahwa 21 sampel (53,8\%) mempunyai $\mathrm{TIBC}<240 \mu \mathrm{g} / \mathrm{dl}, 18$ sampel $(46,2)$ pasien mempunyai TIBC antara 240-350 $\mu \mathrm{g} / \mathrm{dl}$, sedangkan tidak ditemukan peningkatan TIBC $>350$ pada sampel (Tabel 7).

Tabel 7. Distribusi Sampel Berdasarkan nilai TIBC

\begin{tabular}{ccc}
\hline \multirow{2}{*}{ TIBC $(\mu \mathrm{g} / \mathrm{dl})$} & \multicolumn{2}{c}{ Jumlah Sampel } \\
& $\mathrm{n}$ & $(\%)$ \\
\hline$<240$ & 21 & 53,8 \\
$240-350$ & 18 & 46,2 \\
$>350$ & 0 & 0 \\
Total & 39 & 100 \\
\hline
\end{tabular}

Sesuai dengan algoritma yang diterapkan pada penelitian, didapatkan 5 sampel (12,8\%) terdiagnosis anemia defisiensi besi. Nilai penanda anemia defisiensi besi pada sampel tersebut dapat dilihat pada Tabel 8.

Tabel 8. Distribusi sampel berdasarkan penanda diagnosa anemia defisiensi besi

\begin{tabular}{cccccc}
\hline No & $\begin{array}{c}\mathrm{Hb} \\
(\mathrm{g} / \mathrm{dl})\end{array}$ & $\begin{array}{c}\text { MCV } \\
(\mathrm{fl})\end{array}$ & $\begin{array}{c}\text { MCHC } \\
(\%)\end{array}$ & $\begin{array}{c}\text { SI } \\
(\mu \mathrm{g} / \\
\mathrm{dl})\end{array}$ & $\begin{array}{c}\text { S. } \\
\text { Trans } \\
\text { ferin } \\
(\%)\end{array}$ \\
\hline 1 & 7 & 79,5 & 31,9 & 45 & 13,8 \\
2 & 9,2 & 80 & 31,8 & 50 & 19,6 \\
3 & 9,7 & 75,4 & 31,4 & 45 & 19,8 \\
4 & 10 & 80 & 33 & 29 & 13,7 \\
5 & 9,5 & 79 & 31 & 50 & 19,2 \\
\hline
\end{tabular}




\section{BAHASAN}

Penelitian ini bersifat desktiptif dan dilakukan di RSUP Prof. R. D. Kandou Manado periode Oktober 2015 - Desember 2015. Terdapat 39 sampel yang memenuhi kriteria inklusi dan eksklusi. Sampel dengan jenis kelamin laki - laki berjumlah 18 orang (46,2\%), sedangkan yang perempuan berjumlah 21 orang (53,8\%). Berbeda dengan penelitian yang dilakukan oleh Singh et al. ${ }^{5}$ tahun 2013 dimana 61\% dari keseluruhan sampel yang diteliti merupakan laki-laki. IRR tahun 2012 juga melaporkan bahwa jumlah pasien laki-laki yang menjalani hemodialisis tiap tahunnya lebih banyak dari pasien perempuan.

Pada data umur sampel, mayoritas pasien berumur lebih dari 46 tahun. Sama halnya dengan penelitian yang dilakukan oleh Pura et al. ${ }^{11}$ dimana didapatkan 79,2\% pasien PGK berumur $>50$ tahun. Hal ini terjadi karena faktor laju filtrasi glomerulus menurun dalam proses penuaan serta meningkatnya faktor risiko mengidap penyakit komorbid. Penurunan LFG menyebabkan semakin sedikit neuron yang berfungsi, termasuk fungsi dalam produksi hormon eritropoetin yang berakibat pada terjadinya anemia, walaupun penyebab pada anemia pada PGK sendiri multifaktorial. ${ }^{12}$

Semua sampel pada penelitian menderita anemia. Hal ini sesuai dengan penelitian yang dilakukan oleh Singh, ${ }^{11}$ bahwa didapatkan 80-90 pasien PGK memiliki Hb yang rendah. Hal ini didukung oleh teori yang mengatakan bahwa pada PGK terjadi anemia akibat kurangnya produksi hormon eritropoetin, yang merangsang produksi sel darah merah di sumsum tulang. ${ }^{13}$ Disamping itu, anemia pada pasien PGK sering diakibatkan oleh multifaktorial, diantaranya adalah akibat kekurangan nutrisi. ${ }^{14}$ Pada penelitian ini didapati anemia dengan derajat berat pada 11 sampel, anemia dengan derajat sedang pada 26 sampel dan anemia derajat ringan pada 2 sampel. Sementara itu, mayoritas sampel menunjukkan nilai MCV, MCH dan MCHC yang normal yang mendukung teori bahwa sebagian besar anemia pada pasien
PGK disebabkan oleh defisiensi eritropoetin, sehingga menyebabkan MCV, MCH dan MCHC berada dalam batas normal.

Pada penelitian ini didapatkan nilai saturasi transferin paling banyak yang normal sebanyak 28 sampel (71,8\%). Hal ini tidak berbeda dengan penelitian yang dilakukan oleh Patambo et al. bahwa sampel dengan nilai saturasi transferin yang meningkat ialah yang terbanyak. ${ }^{11}$

Terdapat 20 sampel yang memiliki nilai serum iron normal. Hal ini sesuai dengan penelitian yang dilakukan Yendriwati et al. ${ }^{13}$ bahwa sampel dengan serum iron normal adalah yang terbanyak. Walaupun demikian, terdapat 16 sampel (41\%) memiliki nilai serum iron yang menurun. 10 diantaranya dibawah $50 \mu \mathrm{g} / \mathrm{dl}$. Dari 10 (25,6\%) sampel tersebut 5 diantaranya memiliki nilai saturasi transferin dibawah 20\% yang menandakan adanya defisiensi besi.

Pada penelitian ini didapatkan bahwa sampel banyak yang memiliki nilai TIBC menurun lebih banyak daripada yang memiliki nilai TIBC rendah walaupun tidak signifikan. Hal ini sesuai dengan penelitian yang dilakukan oleh Nyoman et al. ${ }^{12}$ bahwa sampel dengan nilai TIBC menurun lebih banyak dibandingkan nilai TIBC normal. TIBC yang menurun pada PGK dapat disebabkan karena meningkatnya feritin atau dapat terjadi pada anemia penyakit kronis yang terjadi inflamasi.

Algoritma penegakan diagnosis anemia defisiensi besi pada penelitian ini menemukan terdapat 5 sampel (12,8\%) yang terdiagnosis anemia defisiensi besi. Sesuai teori, salah satu penyebab defisiensi besi pada pasien PGK terjadi akibat penggunaan ESA, dimana ESA menstimulasi pembentukan sel darah merah dan membutuhkan serum besi sebagai salah satu bahan. ${ }^{15}$ Oleh karena itu, penggunaan ESA harus dikontrol, salah satunya dengan memonitor status besi pasien. Hal lain yang dapat memengaruhi kadar besi pada pasien PGK adalah asupan nutrisi yang kurang, gangguan absorbsi, perdarahan kronik, dan inflamasi atau infeksi. ${ }^{10}$ 


\section{SIMPULAN}

Dari hasil penelitian dan bahasan yang dilakukan dapat disimpulkan sebagai berikut :

1. Yang terbanyak ditemukan ialah anemia derajat sedang, diikuti anemai derajat berat dan ringan.

2. Ditemukan 12,8\% sampel dengan anemia defisiensi besi.

\section{SARAN}

Pada penelitian ini tidak dicatat terapi yang sedang dijalani pasien sehingga tidak diketahui faktor-faktor yang menyebabkan status besi pasien, oleh karena itu untuk penelitian selanjutnya disarankan untuk mencatat terapi atau penatalaksanaan anemia yang sedang dijalani pasien.

Sebaiknya dilakukan perbandingan status besi terhadap pasien yang sudah melakukan terapi untuk mengatasi anemia dengan pasien yang belum melakukan terapi.

Diharapkan pada pasien PGK yang menjalani hemodialisis untuk selalu memantau status besinya.

\section{DAFTAR PUSTAKA}

1. Suwitra K. Penyakit ginjal Kronik. In: Sudoyo AW et al, editors. Buku Ajar Ilmu Penyakit Dalam Jilid II (5th ed). Jakarta: Interna Publishing, 2009; p.1035-40.

2. Thomas R, Kanso A, Sedor JR. Chronic Kidney Disease and Its Complications. Prim Care. 2008;35(2):329-vii.

3. Baradero M, Dayrit M, Siswadi Y. Klien Gangguan Ginjal. Jakarta: EGC, 2009.

4. Arora P. Cronic Kidney Disease. 2015 Apr 07 [cited 2015 Sep 16]. Available from:http://emedicine.medscape.com/ article/238798-overview.

5. Singh AK, Farag YK, Mittal BV, Subramanian KK, Reddy SR, Acharya VN. Epidemiology and risk factors of chronic kidney disease in India - results from the SEEK
(Screening and Early Evaluation of Kidney Disease) study. BMC Nephrology. 2013;14:114-24.

6. Ibrahim $K$, Taboonpong S, Nilmanat $K$. Coping and quality of life among Indonesians undergoing hemodialysis. Thai J Nurs Res. 2009;13(2).

7. Perhimpunan Nefrologi Indonesia (PERNEFRI). $5^{\text {th }}$ Annual Report of Indonesian Renal Registry, 2012

8. Perhimpunan Nefrologi Indonesia (PERNEFRI). $4^{\text {th }}$ Annual Report of Indonesian Renal Registry. 2011

9. Stauffer ME, Fan T. Prevalence of Anemia in Chronic Kidney Disease in the United States. PLoS ONE. 2014;9(1): e84943.

10. Singh AK. Anemia of Chronic Kidney Disease. Clin J Am Soc Nephrol. 2008;3:3-6.

11. Pura L, Supriyadi S, Nugraha GI, Bandiara $\mathbf{R}$, Soelaeman $\mathbf{R}$. Hubungan laju filtrasi glomerulus dengan status nutrisi pada penderita penyakit ginjal kronik predialisis. MKB. 2009;41(1).

12. Ayu P. Nyoman, Suega Ketut, Widiana Gede. Hubungan antara Beberapa Parameter Anemia dan Laju Filtrasi Glomerulus pada Penyakit Ginjal Kronik Pradialisis. J Peny Dalam. 2010;11(3):140-8.

13. Yendriwati. Status besi pada penderita gagal ginjal kronik dalam menetukan diagnosa anemia [Tesis]. Medan: Program Pascasarjana Universitas Sumatra Utara; 2002.

14. Vijil JC. Anemia in Elderly with CKD. American Society of Nephrology 2009.

15. Dalimunthe N. Peningkatan Nilai Parameter Status Besi Reticulocyte Hemoglobin Equivalent setelah pemberian suplemen besi intravena pada pasien hemodialisis reguler. Medan: Universitas Sumatera Utara. 2012. 